Discussion

Papers

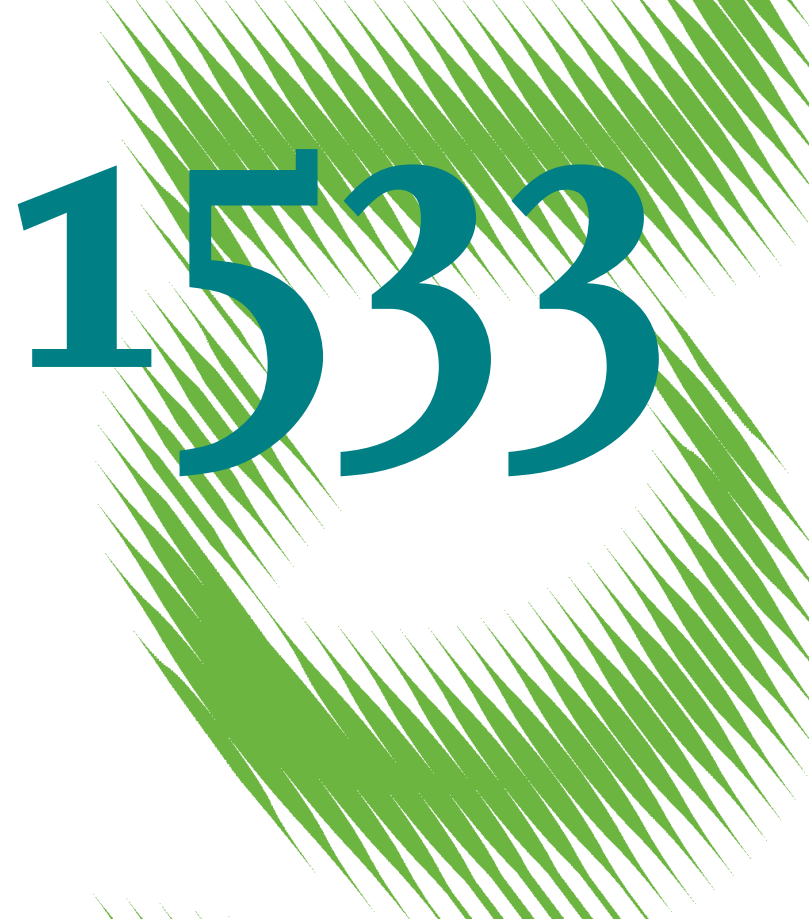

Flipping Journals to Open: Rethinking Publishing Infrastructure 
Opinions expressed in this paper are those of the author(s) and do not necessarily reflect views of the institute.

IMPRESSUM

(C) DIW Berlin, 2015

DIW Berlin

German Institute for Economic Research

Mohrenstr. 58

10117 Berlin

Tel. +49 (30) $89789-0$

Fax +49 (30) $89789-200$

http://www.diw.de

ISSN electronic edition 1619-4535

Papers can be downloaded free of charge from the DIW Berlin website:

http://www.diw.de/discussionpapers

Discussion Papers of DIW Berlin are indexed in RePEc and SSRN:

http://ideas.repec.org/s/diw/diwwpp.html

http://www.ssrn.com/link/DIW-Berlin-German-Inst-Econ-Res.html 


\title{
Flipping journals to open: Rethinking publishing infrastructure
}

\author{
Benedikt Fecher ${ }^{1}$ and Gert G. Wagner ${ }^{2}$
}

December 2015

A first version of the paper is published at

http://blogs.Ise.ac.uk/impactofsocialsciences/2015/12/03/seizing-the-moment-is-our-

understanding-of-open-access-too-shortsighted/. Many thanks to Sascha Friesike, Soenke Bartling, Jonas Kaiser, Lies van Roessel, Jana Schudrowitz and Lorraine Sugar.

\footnotetext{
${ }^{1}$ German Institute for Economic Research (DIW Berlin), Alexander von Humboldt Institute for Internet and Society (Berlin) and Max Planck Institute for the History of Science (Berlin). benedict.fecher@hiig.de

2 German Institute for Economic Research (DIW Berlin), Technical University of Berlin (TUB), MPI for Human Development (Berlin), member of Germany's "National Academy of Science and Engineering (acatech)"
} 


\begin{abstract}
Open access means that research outputs, such as articles and data, are free of restrictions on access and free of restrictions on use. In the light of recent market developments in academic publishing, we argue in this essay that the discourse about open access must include a discussion about research infrastructure and innovation in academic publishing.
\end{abstract}

Keywords: Open access, innovation, research infrastructure, science policy

JEL Classification: D02, H41, L17, Z13 


\section{Introduction}

In October 2015 the entire editorial board of the journal Lingua resigned and announced they would launch a new journal named Glossa (Greenberg 2015). ${ }^{3}$ Lingua's executive editor Johan Rooryck said the reason for the resignation was that Elsevier, which publishes Lingua, did not comply with the editors' request to turn the journal into an open access publication (Krishnan, 2015). Lingua has existed since 1949 and is among the top-3 linguistic journals on Google Scholar. The Lingua/Glossa case is a good opportunity to reflect upon our understanding of open access against the backdrop of information infrastructure and innovation in academic publishing.

\section{Open access in a nutshell}

Broadly speaking, open access means that research outputs, such as articles and data, are free of restrictions on access and free of restrictions on use. The call for open access for articles is often justified with the fact that essential parts of the scientific publishing process, for example writing an article and reviewing it, are completed by the scientific community. Nonetheless, most of the research-that is to large degree financed by public funds-is hidden behind paywalls. This situation is aggravated by the fact that libraries are increasingly struggling with high license fees (RLUK 2015, University Libraries, 2015) for journals and debatable package deals, while publishing houses like Elsevier, Wiley or Springer seem highly profitable (Monbiot 2011). To put it provocatively: The costs to access research outputs are being paid for twice by the taxpayers: for the researchers who produce articles and the libraries that purchase the articles. The discussion about open access is understandably heated.

Publishers argue, on the other hand, that revising articles and organizing the publication process costs money (van Noorden 2013). Moreover, their journals fulfill an important curation task in an increasingly confusing publication landscape. The latest report by the STM association counted 28,000 peer reviewed journals that publish more than 2.5 million

\footnotetext{
3"Lingua" means tongue in Latin. "Glossa" means tongue in ancient Greek. In Glossa's case, one could say the naming is meant symbolically.
} 
articles per year (Ware \& Mabe, 2015). ${ }^{4}$ The report also states that the number of articles has continuously increased for more than two centuries. For researchers, it becomes more and more difficult to identify quality in the jungle of articles. Indeed, established journals provide orientation.

Research funders, research associations, institutes and universities alike have developed open access strategies, proving that the demand for open access is no longer an idealistic one. In November 2015 representatives from the leading Austrian research organizations announced that all publications financed with public funds will be available online without restrictions by 2025 (Bauer et al. 2015). In October 2015, the Berlin Senate mapped out an Open Access strategy for publicly financed research in Berlin (Bruch et al. 2015). It is common sense by now that scientific output should be freely available online. With new online distribution channels, the traditional mediator role of scientific publishers has come under scrutiny as the Lingua/Glossa case shows.

\section{Do we think open access far enough?}

Looking at the mindsets of many academic researchers and at initiatives undertaken by research organizations, one could question if our understanding of open access in the academic community goes far enough.

Often researchers believe that open access publications are of lower quality - a belief that is of course not justified by definition but frequently perpetuated by established publishers. This is slightly paradoxical, since many publishing houses offer what they call "golden road" to open access (Working Group on Expanding Access to Published Research Findings, 2012). Here journals make their articles openly accessible immediately upon publication for a ransom, the so-called article processing charge (APC). Some communities (e. g. for a long time economists) also offer renowned working paper series that are published under open access licenses online, but without the traditional peer review.

${ }^{4}$ STM stands for "International Association of Scientific, Technical and Medical Publishers" 
The belief that publishing under an open access license is still a less prestigious way of publishing may be owed to the high number of dubious open access journals that have been mushrooming in the recent years. These "predatory journals" charge high publication fees to authors without providing the editorial and publishing services of legitimate journals (Bartholomew 2014). Researchers that do not deal with this topic are having troubles separating the wheat from the chaff. They stick with their well-known journals.

Looking at the open access initiatives undertaken by many research funders, one could get the impression that the job is done by establishing publishing funds. These funds can be used to cover the costs of golden open access. As an illustration: for Lingua, this opt-in for open access costs $\$ 1,800^{5}$, which is about average (the average APC is $f 1,741$ ) (Andrew 2015). Many "golden open access models" represent a redistribution of costs that is still to the detriment of academia. Publishing funds are indeed useful to make single articles from relevant journals available to everyone. They are, however, an insufficient response to the urging question of how the scientific community should manage the access to its outputs in an increasingly digitized society.

Put provocatively: It is for the researchers' conservatism on the one hand and the research organizations' passivity on the other hand that open access is rather a business model than a sustainable strategy to organize knowledge in the 21st century. Our understanding of open access in the scientific community is perhaps too shortsighted.

\section{Open access and innovation}

With increasing digitization, the way research is conducted, communicated and critiqued has changed. Open access also means rethinking the way the publishing process is organized and how quality can be identified.

One vivid example for a more digitally savvy way of publishing are a few mega journals such as PLOS ONE. ${ }^{6}$ PLOS ONE is more of a platform than a single journal. It is multidisciplinary, open access and has no limit for the number of articles it publishes. In fact, by number of

\footnotetext{
${ }^{5}$ https://www.elsevier.com/journals/lingua/0024-3841/open-access-options\#fee

${ }^{6}$ http://www.plosone.org/
} 
articles, PLOS ONE is by far the largest journal worldwide. Articles on PLOS ONE are published after a review for scientific soundness. The judgment of an editor about relevance of the paper does not matter. The scientific community then evaluates an article through citations, but also through shares on Twitter and Facebook. In other words: the relevance and impact of a paper published in PLOS ONE is not a matter of ex-ante judgment of an editor but an ex-post demonstration of the readers. Furthermore, PLOS ONE has a farreaching data availability policy and shows how often data has been used on figshare (http://figshare.com/), an online data repository.

Even though PLOS ONE has no limit for the number of articles it publishes in a month and is rather focused on article-based metrics, it has quite an impressive impact factor of about 3.5 in 2013/2014 (CiteFactor 2015). PLOS ONE is financed by article processing charges on a notfor-profit model. Established publishing houses are also investing in the mega journal model, for example $O^{\prime}$ Reilly with PeerJ ${ }^{7}$ or Macmillan with Scientific Reports ${ }^{8}$, which belongs to the family of Nature journals. All those journals charge APCs.

Mega journals take a form of research into account that is faster moving, increasingly multidisciplinary and whose impact is not necessarily accessible prior to a publication. The trimmed-down review allows for articles to be published faster than with the traditional review model. When it takes several years from the submission of an article to its publication, one can indeed question if the old review model is still zeitgeisty enough (Björk, 2011).

In comparison to the established journal models, the review process at mega journals fulfills more of a scrutinizing than a curating role (Fecher 2015). One can indeed also look critically at the mega journal model; however, they do at least try to shake the dust off of the book age by implementing new and faster mechanisms to identify quality by ex-post citation measures. They are furthermore a home for research that cannot be fit into a single discipline, which is important in times when research problems are increasingly multidisciplinary and require collaborative effort.

\footnotetext{
${ }^{7}$ https://peerj.com/

${ }^{8}$ http://www.nature.com/srep/
} 
PLOS ONE and the other mega journals do not understand open access solely as the access to articles; they understand open access also as a way publishing can be organized and presented in a digital age.

\section{Open access and infrastructure}

The market for scientific publishing is undergoing a similar process as other industries did with digitization, such as the newspaper or music industry. Old players position themselves anew (e.g., newspapers test new content formats and payment models), new players emerge (e.g., clickbait-journalism) and less strong players disappear (e.g., "print crisis") (Anderson et al. 2015). In the realignment of market players for scientific publishing, academia has to be careful not to come out empty-handed.

Looking at the innovative players in online publishing, one can see that many have a commercial background. In an interview with irights (https://irights.info/) Lambert Heller from the Open Science Lab of the German National Library of Science and Technology (TIB Hannover) pointed to the market power of startups and traditional publishers that invest cleverly in digital information infrastructure (irights 2015). This, according to Heller, applies not only to online journals but also to social networks for researchers, such as Researchgate ${ }^{9}$ and academia.ed $u^{10}$, reference managers such as Mendeley ${ }^{11}$, and code and data repositories such as figshare ${ }^{12}$ and github ${ }^{13}$. The historian Philip Mirowski (2011) even sees a "neoliberal project" in the overall development. With respect to the formation of new players in the market for scientific publishing, Lambert Heller poses the question: how free does academia want its operation system to be?

One does not have to go as far as to describe the development in online publishing as a purely neoliberal project. What is true, however, is that many critical nodes in the digital information infrastructure are already occupied by commercial players. Of course, this is not necessarily a bad thing. However, past experiences, including the dependence on mega

\footnotetext{
${ }^{9}$ http://www.researchgate.net/

${ }^{10}$ https://www.academia.edu/

${ }^{11}$ https://www.mendeley.com/

12 http://figshare.com/

${ }^{13}$ https://github.com/
} 
publishers, should make academics take an even more critical stance. In this regard, open access is also a question of who owns the critical information infrastructure for online publishing or-put differently-which parts of its value creation academia wants to outsource this time.

If there is a technology driven reorganization of the market for scientific publishing is going on, why should academia not play a more active role than in the past?

\section{The Lingua-to-Glossa-Move as a role model for others?}

This is where the case Lingua/Glossa comes into play again. The resignation of Lingua's editorial board and its reorganization in the to-be-founded journal Glossa could get the ball rolling, and other journals could follow the example.

The outlook for Glossa is good. For the first five years, the journal will be completely free for authors and readers thanks to funding from the Netherlands Organization for Scientific Research and the Association of Dutch Universities (Greenberg, 2015). According to Rooryck, the article processing charge for gold open access will then not be higher than $400 €$. If that holds true, the APCs (article processing charge) will be reduced significantly compared to the $\$ 1,800$ at Lingua. The organization of content-from the production of articles, to the peer review, to the publication-remains in the hands of academia.

Perhaps equally important is the fact that the former editorial board of Lingua will regroup in the new journal Glossa. One of the biggest issues for new journals is to build up a reputation. At Glossa, the good reputation is there from the outset.

This combination of public funding, low APCs, self-organization and community backing already seems a promising model for open access. The Max Planck Digital Library just recently put forward a study on the transformation of the subscription-driven system for scientific publications to an efficient and budget-neutral open access model (Schimmer 2015). If not a call for rebellion, the Lingua/Glossa case shows at least quite plainly that the negotiations about the costs of access are reopened. 
The Lingua/Glossa case also reminds us that open access means more than just the access to an article. It also means rethinking the process of publishing (as PLOS ONE, PeerJ and Nature Scientific Reports show) as well as the infrastructure used to publish research outputs.

The scientific community now has the chance to (at least to some extent) free itself from its path dependence and to rethink publishing in a digital society. The move of the editors of Lingua to Glossa could lead by example. 


\section{References}

1. C. Anderson, E. Bell, C. Shirky, Post-industrial journalism: Adapting to the present. Geopolitics, History, and International Relations. 7, 32-123 (2015).

2. R. E. Bartholomew, Science for sale: the rise of predatory journals. Journal of the Royal Society of Medicine. 107, 384-385 (2014).

3. B.-C. Björk, A Study of Innovative Features in Scholarly Open Access Journals. Journal of Medical Internet Research. 13, e115 (2011).

4. C. Bruch, M. Kindling, K. Mruch, D. Schobert, M. Voigt, "Open-Access-Strategie für Berlin: wissenschaftliche Publikationen für jedermann zugänglich und nutzbar machen" (Technische Universität Berlin, Berlin), (available at https://opus4.kobv.de/opus4-tuberlin/frontdoor/index/index/docld/6657).

5. Bruno Bauer et al., Empfehlungen für die Umsetzung von Open Access in Österreich (2015), doi:10.5281/zenodo.33178.

6. CiteFactor, CiteFactor. Academic Scientific Journals (2014), (available at http://www.citefactor.org/journal-impact-factor-list-2014_P.html).

7. L. Dobusch, Open Access Network Austria präsentiert 16-Punkte-Plan für Vollumsieg auf Open Access bis 2025 (2015), (available at https://netzpolitik.org/2015/openaccess-network-austria-praesentiert-16-punkte-plan-fuer-vollumstieg-auf-openaccess-bis-2025/).

8. Elsevier, "Open access options," (available at https://www.elsevier.com/journals/lingua/0024-3841/open-access-options\#fee).

9. B. Fecher, Academic publishing can free itself from its outdated path dependence by looking to alternative review mechanisms. LSE Impact Blog, (available at http://blogs.Ise.ac.uk/impactofsocialsciences/2014/09/16/academic-publishing-pathdependence-qwerty/).

10. J. Greenberg, Editors of the Journal Lingua Protest-Quit in Battle for Open Access (2015), (available at http://www.wired.com/2015/11/editors-of-the-journal-linguaprotest-quit-in-battle-for-open-access/).

11. irights, Lambert Heller: "Wie frei soll das Betriebssystem der Wissenschaft sein?" irights info. Urheberrecht und kreatives Schaffen in der digitalen Welt (2015), (available at https://irights.info/artikel/lambert-heller-wie-frei-soll-dasbetriebssystem-der-wissenschaft-sein/26413). 
12. A. Krishnan, Leaves of gold: An Interview with Johan Rooryck (2015), (available at http://unravellingmag.com/dialogue/open-access-publishing/).

13. P. Mirowski, Science-mart: privatizing American science (Harvard University Press, Cambridge, Mass, 2011).

14. G. Monbiot, Academic publishers make Murdoch look like a socialist (2011), (available at http://www.theguardian.com/commentisfree/2011/aug/29/academicpublishers-murdoch-socialist).

15. R. L. RLUK, Journal pricing FAQ (2015), (available at http://www.rluk.ac.uk/strategicactivity/projects/aspi/journal-pricing-faq/).

16. Schimmer, Ralf, Geschuhn, Kai Karin, Vogler, Andreas, Disrupting the subscription journals' business model for the necessary large-scale transformation to open access (2015), doi:10.17617/1.3.

17. Science, Sciencelnsider, (available at http://news.sciencemag.org/peopleevents/2014/06/output-drops-worlds-largest-open-access-journal).

18. University of Washingtion University Libraries, The Economics of Journal Publishing, (available at http://www.lib.washington.edu/scholpub/facts/economics).

19. R. Van Noorden, Open access: The true cost of science publishing. Nature. 495, 426429 (2013).

20. M. Ware, M. Mabe, "The STM Report. An overview of scientific and scholarly journal publishing." (The Hague, 2015), (available at http://www.stmassoc.org/2015_02_20_STM_Report_2015.pdf).

21. Working Group on Expanding Access to Published Research Findings, "Accessibility, sustainability, excellence: how to expand access to research publications" (2012). 